\title{
Phosphine resistance, respiration rate and fitness consequences in stored-product insects
}

\author{
Marco Aurélio G Pimentel, ${ }^{1}$ Lêda Rita D’A Faroni, ${ }^{2}$ Marcos R Tótola ${ }^{3}$ and \\ Raul Narciso C Guedes ${ }^{1 *}$ \\ ${ }^{1}$ Departamento de Biologia Animal, Universidade Federal de Viçosa (UFV), Viçosa, MG 36570-000, Brazil \\ ${ }^{2}$ Departamento de Engenharia Agrícola, Universidade Federal de Viçosa (UFV), Viçosa, MG 36570-000, Brazil \\ ${ }^{3}$ Departamento de Microbiologia, Universidade Federal de Viçosa (UFV), Viçosa, MG 36570-000, Brazil
}

\begin{abstract}
Resistance to fumigants has been frequently reported in insect pests of stored products and is one of the obstacles in controlling these pests. The authors studied phosphine resistance and its physiological basis in adult insects of 12 populations of Tribolium castaneum (Herbst) (Tenebrionidae), ten populations of Rhyzopertha dominica (F.) (Bostrichidae) and eight populations of Oryzaephilus surinamensis L. (Silvanidae) from Brazil, and the possible existence of fitness costs associated with phosphine resistance in the absence of this fumigant. The bioassays for the detection of phosphine resistance followed the FAO standard method. The production of carbon dioxide and the instantaneous rate of population increase $\left(r_{i}\right)$ of each population of each species were correlated with their resistance ratios at the $\mathrm{LC}_{50}$. The resistance ratio at $\mathrm{LC}_{50}$ in $T$. castaneum ranged from 1.0to 186.2-fold, in $R$. dominica from 2.0- to 71.0-fold and in $O$. surinamensis from 1.9- to 32.2-fold. Ten populations of $T$. castaneum, nine populations of $R$. dominica and seven populations of $O$. surinamensis were resistant to phosphine. In all three species there was significant association $(P<0.05)$ between respiration rate and phosphine resistance. The populations with lower carbon dioxide production showed a higher resistance ratio, suggesting that the lower respiration rate is the physiological basis of phosphine resistance by reducing the fumigant uptake in the resistant insects. Conversely, populations with higher $r_{i}$ showed lower resistance ratios, which could indicate a lower rate of reproduction of the resistant populations compared with susceptible populations. Thus, management strategies based on the interruption of phosphine fumigation may result in reestablishment of susceptibility, and shows good potential for more effective management of phosphine-resistant populations.
\end{abstract}

(c) 2007 Society of Chemical Industry

Keywords: Tribolium castaneum; Rhyzopertha dominica; Oryzaephilus surinamensis; fumigant resistance; carbon dioxide production; rate of population growth

\section{INTRODUCTION}

Phosphine has been a widely used fumigant for the control of stored-product insects for almost half a century. ${ }^{1,2}$ It is by far the most widely used fumigant worldwide, because of its low cost, its rapid diffusion in air and its low residues. ${ }^{2,3}$ These advantages have contributed to an increased dependence on this fumigant. ${ }^{2}$ However, the long-term use of a single fumigant increases the risk of development of resistance in pest populations. ${ }^{3-6}$ Indeed, resistance to fumigants is an increasing problem in controlling stored-product insects throughout the world. ${ }^{1,7}$ The problem of resistance is particularly acute since the prohibition, by the Montreal Protocol, 8 of methyl bromide which was the only alternative fumigant for stored-product pests until now. In addition, the lack of ideal airtight conditions for fumigation in most storage units increases the frequency of control failures and consequently increases the frequency of applications. ${ }^{2,6,9,10}$ This results in an increased selection pressure for phosphine resistance. ${ }^{2,11}$

A global survey undertaken by the Food and Agriculture Organization (FAO) in 1972/1973 showed that about $10 \%$ of the collected populations in the world contained phosphine-resistant individuals, but phosphine-resistant populations were not found in Brazil. $^{7}$ Since this survey, some pest control failures with phosphine have been reported in Brazil, allegedly on account of resistance. ${ }^{10,12}$ Moreover, phosphine resistance in stored-product insects has been documented in several neighbouring South American countries. ${ }^{7,10,12}$ Except for the global survey undertaken by the $\mathrm{FAO},{ }^{7}$ surveys for phosphine resistance in stored-product insects in Brazil are rare. There are only two reports showing phosphine resistance in Brazilian populations of Rhyzopertha dominica (F.) (Coleoptera: Bostrichidae), Tribolium castaneum (Herbst) (Coleoptera: Tenebrionidae), Sitophilus oryzae (L.) (Coleoptera: Curculionidae)

* Correspondence to: Raul Narciso C Guedes, Departamento de Biologia Animal, Universidade Federal de Viçosa, Viçosa, MG 36571-000,Brazil E-mail: guedes@ufv.br

(Received 2 October 2006; revised version received 28 December 2006; accepted 16 February 2007)

Published online 27 June 2007; DOI: 10.1002/ps.1416 
and Cryptolestes ferrugineus (Stephens) (Coleoptera: Cucujidae). ${ }^{10,12}$ However, the spread and severity of phosphine resistance in populations of $R$. dominica, T. castaneum and Oryzaephilus surinamensis L. (Coleoptera: Silvanidae) from Brazil are not known because the studies carried out so far have been based on discriminating concentration tests.

Resistance to insecticides is often accompanied with fitness costs, such as a decreased rate of development, fecundity, survival or mating competitiveness relative to susceptible insects. ${ }^{13-18}$ Differences in the biological parameters affecting the growth rate of insect populations are fundamental to insecticide resistance management, ${ }^{14,19}$ because, in this case, the frequency of resistant individuals may decrease with time. ${ }^{15,19}$ However, resistant strains may have a fitness advantage under particular conditions, and resistant individuals may not decrease over time. ${ }^{14,19,20-23}$

An understanding of the mechanism of phosphine resistance in stored-product insects is also fundamental to phosphine resistance management. The prevailing mechanism of phosphine resistance in these insects involves a reduced uptake of the fumigant, a process designated as active exclusion. ${ }^{24,25}$ This process may be closely linked with insect respiration rate, which is not usually determined in studies of phosphine resistance. Respiration is also a good index of the insect's physiological responses to the environment in which it is exposed. ${ }^{11,26,27}$

Survey and monitoring of changes in the susceptibility of insects are fundamental for phosphine resistance management. It is possible to evaluate the efficiency of the management strategies adopted to delay the evolution of resistance. ${ }^{13}$ Phosphine resistance management studies are of particular interest in the control of resistant populations. ${ }^{14}$ Therefore, the aim of the present study was (1) to carry out a preliminarily assessment of the spread and severity of phosphine resistance in populations of $R$. dominica, $T$. castaneum and $O$. surinamensis in Brazil, (2) to verify if the prevailing mechanism of phosphine resistance in these populations involves a reduced respiration rate and (3) to verify the existence of fitness disadvantages of phosphine resistance in the absence of phosphine by correlating the instantaneous rate of population increase $\left(r_{\mathrm{i}}\right)$ with the resistance levels observed in adult populations of the three species.

\section{EXPERIMENTAL METHODS}

\subsection{Insects}

Use was made of 12 populations of $T$. castaneum, ten populations of $R$. dominica and eight populations of $O$. surinamensis collected at 17 sites in four Brazilian states (Table 1). These populations were reared in glass bottles $(1.5 \mathrm{~L})$ in the laboratory $\left(28 \pm 2{ }^{\circ} \mathrm{C}\right.$, $70 \pm 5 \% \mathrm{RH})$. Broken corn grains were used as food source for $T$. castaneum and $O$. surinamensis, and whole wheat grains were used for $R$. dominica (13\% moisture content). Grains were previously disinfected and kept at $-18^{\circ} \mathrm{C}$ to avoid field cross-infestation.

\subsection{Concentration-response curves}

Discriminating concentrations recommended by the FAO were used as a starting point for concentration-mortality curves $\left(0.03 \mathrm{mg} \mathrm{L}^{-1}\right.$ for $R$. dominica, $0.04 \mathrm{mg} \mathrm{L}^{-1}$ for $T$. castaneum and $0.05 \mathrm{mg} \mathrm{L}^{-1}$ for $O$. surinamensis). ${ }^{28}$ The concentration of the phosphine source was always checked before the bioassays. Depending on the mortality at these concentrations, higher or lower concentrations were used to find the range that resulted in $0-100 \%$ mortality for each population. This resulted in 5-8 concentrations being tested for each population within the recognized phosphine concentration range.

Fumigation of adults was based on the FAO method and took place at $25^{\circ} \mathrm{C}$ and $70 \% \mathrm{RH} .{ }^{28}$ Phosphine

Table 1. Origin of the Brazilian populations of Tribolium castaneum, Rhyzopertha dominica and Oryzaephilus surinamensis

\begin{tabular}{|c|c|c|c|c|}
\hline County & State & Storage facility & Time & Species $^{a}$ \\
\hline Água Boa & Mato Grosso & Warehouse & August 2004 & $\mathrm{~T}$ and $\mathrm{R}$ \\
\hline Aguanil & Minas Gerais & Farm wood store & May 2005 & $\mathrm{~T}$ \\
\hline Alfenas & Minas Gerais & Metallic bin & April 2004 & $\mathrm{~T}$ \\
\hline Astolfo Dutra & Minas Gerais & Industry of Foods & September 2005 & $\mathrm{O}$ \\
\hline Bom Despacho & Minas Gerais & Metallic bin & May 2005 & $\mathrm{~T}, \mathrm{R}$ and $\mathrm{O}$ \\
\hline Bragança Paulista & São Paulo & Farm wood store & March 2005 & $\mathrm{~T}$ \\
\hline Campos de Júlio & Mato Grosso & Metallic bin & June 2004 & $\mathrm{~T}$ and $\mathrm{R}$ \\
\hline Guaxupé & Minas Gerais & Metallic bin & August 2005 & $\mathrm{O}$ \\
\hline Nova Era & Minas Gerais & Warehouse & May 2005 & $\mathrm{~T}$ and $\mathrm{R}$ \\
\hline Palmital & São Paulo & Metallic bin & March 2005 & $\mathrm{R}$ \\
\hline Piracicaba & São Paulo & Laboratory & August 2004 & T and $R$ \\
\hline Rio Verde & Goiás & Metallic bin & July 2004 & T and $\mathrm{R}$ \\
\hline Sacramento & Minas Gerais & Warehouse & May 2005 & $\mathrm{O}$ \\
\hline Uberlândia & Minas Gerais & Metallic bin & August 2004 & $\mathrm{~T}, \mathrm{R}$ and $\mathrm{O}$ \\
\hline Unaí & Minas Gerais & Metallic bin & August 2004 & $\mathrm{~T}, \mathrm{R}$ and $\mathrm{O}$ \\
\hline Unaí II & Minas Gerais & Metallic bin & July 2004 & $\mathrm{O}$ \\
\hline Viçosa & Minas Gerais & Laboratory & March 2004 & $\mathrm{~T}, \mathrm{R}$ and $\mathrm{O}$ \\
\hline
\end{tabular}

a $\mathrm{T}=$ Tribolium castaneum, $\mathrm{R}=$ Rhyzopertha dominica and $\mathrm{O}=$ Oryzaephilus surinamensis. 
(ca $86 \%$ pure) was produced using aluminium phosphide tablets $(0.6 \mathrm{~g})$ in acidified water (5\% sulfuric acid). Non-sexed adult beetles ( $2-4$ weeks old) were confined in ventilated plastic containers inside gas-tight desiccators. There were 50 adults per container and two containers per desiccator. Phosphine was injected with gas-tight syringes through a septum in the lid of each desiccator to produce the required concentration. After fumigation, the containers were removed from the desiccators and kept for 14 days $\left(25^{\circ} \mathrm{C}\right.$ and $\left.70 \% \mathrm{RH}\right)$, after which mortality was assessed.

\subsection{Respirometry assays}

The production of carbon dioxide was measured in a carbon dioxide analyser (TR 2; Sable System International, Las Vegas, USA) using methods adapted from earlier work. ${ }^{23,29}$ A series of $25 \mathrm{~mL}$ flasks was used, each flask containing 20 insects of each population in a completely closed system. Three replicates were used for each population and carbon dioxide production was measured in each flask under controlled temperature $\left(25^{\circ} \mathrm{C}\right)$ and after a period of $5 \mathrm{~h}$ acclimatization. Carbon dioxide-free air was injected into the flasks for $2 \mathrm{~min}$ at $600 \mathrm{~mL} \mathrm{~min} \mathrm{~m}^{-1}$. An infrared reader was connected to the outlet of the system to quantify carbon dioxide ( $\mu \mathrm{mol})$. Respiration rate was not normalized by weight since it is likely to mask the physiological basis of insecticide resistance and its mitigation. ${ }^{23}$

\subsection{Instantaneous rate of population growth $\left(r_{\mathrm{i}}\right)$}

The instantaneous rate of increase $r_{\mathrm{i}}$ was measured in petri dishes $(140 \times 10 \mathrm{~mm})$ with $40 \mathrm{~g}$ of whole wheat grains (13\% moisture content) for $R$. dominica, and with $40 \mathrm{~g}$ of broken maize grains (13\% moisture content) for $T$. castaneum and $O$. surinamensis. Ten dishes were infested with 20 non-sexed adults $\left(2-4\right.$ weeks old) and maintained at $25 \pm 2{ }^{\circ} \mathrm{C}, 70 \pm$ $5 \% \mathrm{RH}$. The number of live insects was counted after 60 days. The instantaneous rate of increase in each population was calculated as

$$
r_{\mathrm{i}}=\ln \left(N_{\mathrm{f}} / N_{0}\right) / \Delta t
$$

where $N_{\mathrm{f}}$ is the final number of insects alive, $N_{0}$ is the initial number of insects and $\Delta t$ is the duration of the experiment. $^{30}$

\subsection{Statistical analysis}

Concentration-response data were submitted to probit analysis (PROC PROBIT), generating concentration-mortality curves. ${ }^{31}$ The resistance ratios (RRs) and confidence intervals $(P<0.95)$ were also calculated as described elsewhere. ${ }^{32}$ Carbon dioxide production $\left(\mu \mathrm{mol} \mathrm{h}^{-1}\right.$ insect $\left.^{-1}\right)$ and the instantaneous rate of increase $r_{\mathrm{i}}$ were subjected to analysis of variance followed by Tukey's multiple range test $(P<0.05$, PROC GLM). ${ }^{31}$ Data for carbon dioxide production, $r_{\mathrm{i}}$ and resistance ratio $\left(\mathrm{LC}_{50}\right)$ were subjected to regression analysis (PROC REG). ${ }^{31}$

\section{RESULTS}

\subsection{Phosphine resistance}

Concentration-response curves for the populations of $T$. castaneum, $R$. dominica and $O$. surinamensis exposed to phosphine are presented in Tables 2, 3 and 4. Mortality values predicted by the probit model did not differ significantly from the bioassay observed values $(P>0.05)$, and the probit model was therefore used for the concentration-mortality analyses. Lower slopes of concentration-mortality curves suggest heterogeneity of response to phosphine within a population. ${ }^{32}$ The majority of the slopes of the concentration-mortality curves were similar among the populations of $T$. castaneum, $R$. dominica and $O$. surinamensis, except for some populations of each with higher slopes compared with those of the other populations (Tables 2, 3 and 4).

Concentration-response curves were used to identify a standard susceptible population for each of

Table 2. Relative toxicity of phosphine to 12 populations of Tribolium castaneum

\begin{tabular}{|c|c|c|c|c|c|c|c|c|}
\hline Population & $N^{\mathrm{a}}$ & $\begin{array}{c}\text { Slope } \\
( \pm \text { SEM) }\end{array}$ & $\begin{array}{c}\mathrm{LC}_{50}(95 \% \mathrm{FL}) \\
\left(\mathrm{mg} \mathrm{L}^{-1}\right)\end{array}$ & $\begin{array}{c}\mathrm{RR}(95 \% \mathrm{CL}) \\
\mathrm{LC}_{50}\end{array}$ & $\begin{array}{c}\mathrm{LC}_{95}(95 \% \mathrm{FL}) \\
\left(\mathrm{mg} \mathrm{L}^{-1}\right)\end{array}$ & $\begin{array}{c}\mathrm{RR}(95 \% \mathrm{CL}) \\
\text { LC95 }\end{array}$ & $\chi^{2}$ & $P$ \\
\hline Água & 0 & $46( \pm 0.39)$ & $2(0$ & 1 & 060 & 1 & 8.99 & 0. \\
\hline Aguanil & 500 & $2.37( \pm 0.22)$ & $0.02(0.02-0.02)$ & $1.0(0.8-$ & $10(0$ & $1.6(1.1-$ & 0.94 & 0.82 \\
\hline Piracicaba & 450 & $3.15( \pm 0.27)$ & $0.04(0.04-0.05)$ & $2.1(1.7-2.5)$ & $0.22(0$. & $3.7(2.6-5.3)$ & 7.17 & 0.13 \\
\hline Bragança Paulista & 400 & $0.81( \pm 0.13)$ & $0.05(0.02-0.09)$ & $2.6(1.4-5.0)$ & $5.64(2.46-26.29)$ & 95.6 (31.4-290.5) & 4.43 & 0.22 \\
\hline Nova Era & 400 & $7.92( \pm 0.65)$ & 0.07 (0.06-0.07) & $3.2(2.9-3.6)$ & $0.10(0.09-0.11)$ & $1.7(1.4-2.1)$ & 1.23 & 0.54 \\
\hline Rio Verde & 750 & $4.35( \pm 0.34)$ & $0.74(0.68-0.79)$ & $37.0(32.4-42.2)$ & $1.77(1.61-1.98)$ & $29.6(24.0$ & 8.41 & 0.21 \\
\hline Viçosa & 500 & 2.22 & $0.81(C$ & $40.6(34$. & 4.49 & $75.3(50$ & 5.79 & 0.12 \\
\hline Uberl ${ }^{a}$ ndia & 800 & $3.39( \pm 0.36)$ & $0.84(0$. & $41.9(35.3$ & $2.56(2$ & $42.8(34.0$ & 7.31 & 0.29 \\
\hline Alfenas & 650 & $2.67( \pm 0.24)$ & $0.96(0.87-1.05)$ & $47.9(41.6-55.3)$ & $3.95(3.20-5.29)$ & $66.2(48.6-90.3)$ & 4.72 & 0.19 \\
\hline Unaí & 700 & $2.82( \pm 0.30)$ & $1.03(0.84-1.19)$ & $51.4(42.1-62.9)$ & $3.94(3.40-4.85)$ & $66.1(51.3-\varepsilon$ & 3.74 & 0.15 \\
\hline am & 850 & 2.39 & 1.25 & & 2.09 & & 2.28 & 0.68 \\
\hline Bom Despacho & 650 & $3.91( \pm 0.26)$ & $3.72(3.48-3.99)$ & $186.2(164.3-211.0)$ & $9.80(8.54-11.67)$ & $164.1(128.9-208.9)$ & 3.99 & 0.14 \\
\hline
\end{tabular}

${ }^{a} N=$ number of insects.

b Standard susceptible population. 
Table 3. Relative toxicity of phosphine to ten populations of Rhyzopertha dominica

\begin{tabular}{|c|c|c|c|c|c|c|c|c|}
\hline Population & $N^{a}$ & $\begin{array}{c}\text { Slope } \\
( \pm \text { SEM) }\end{array}$ & $\begin{array}{c}\mathrm{LC}_{50}(95 \% \mathrm{FL}) \\
\left(\mathrm{mg} \mathrm{L}^{-1}\right)\end{array}$ & $\begin{array}{c}\mathrm{RR}(95 \% \mathrm{CL}) \\
\mathrm{LC}_{50}\end{array}$ & $\begin{array}{c}\mathrm{LC}_{95}(95 \% \mathrm{FL}) \\
\left(\mathrm{mg} \mathrm{L}^{-1}\right)\end{array}$ & $\begin{array}{c}\mathrm{RR}(95 \% \mathrm{CL}) \\
\text { LC }_{95}\end{array}$ & $\chi^{2}$ & $P$ \\
\hline Piracicabab & 700 & $2.01( \pm 0.15)$ & $0.08(0.07-0.09)$ & 1.0 & $0.54(0.44-0.70)$ & 1.0 & 4.39 & 0.49 \\
\hline Viçosa & 1000 & $1.41( \pm 0.10)$ & $0.17(0.14-0.19)$ & $2.0(1.6-2.5)$ & $2.44(1.77-3.66)$ & $4.5(2.9-7.0)$ & 1.39 & 0.71 \\
\hline Campos de Júlio & 450 & $3.22( \pm 0.35)$ & $0.20(0.17-0.21)$ & $2.4(2.0-2.8)$ & 0.63 (0.50-0.89) & $1.2(0.8-1.7)$ & 5.81 & 0.12 \\
\hline Nova Era & 600 & $1.34( \pm 0.10)$ & $0.23(0.18-0.27)$ & $2.7(2.1-3.5)$ & $3.82(2.45-6.84)$ & $7.1(4.0-12.4)$ & 6.36 & 0.27 \\
\hline Água Boa & 1000 & $1.38( \pm 0.09)$ & 0.34 (0.29-0.39) & $4.1(3.4-5.1)$ & 5.29 (3.83-7.94) & 9.8 (6.3-15.2) & 5.00 & 0.29 \\
\hline Rio Verde & 650 & $2.12( \pm 0.15)$ & $2.40(2.12-2.70)$ & 29.0 (24.0-35.2) & $14.33(11.17-19.80)$ & 26.5 (18.2-38.4) & 5.79 & 0.12 \\
\hline Bom Despacho & 450 & $4.33( \pm 0.42)$ & $3.23(3.00-3.46)$ & 39.2 (33.2-46.2) & 7.75 (6.72-9.50) & $14.3(10.7-19.1)$ & 5.84 & 0.12 \\
\hline Unaí & 650 & $5.74( \pm 0.45)$ & 3.84 (3.63-4.02) & $46.5(39.7-54.4)$ & 7.42 (6.84-8.24) & 13.6 (10.6-17.6) & 6.12 & 0.11 \\
\hline Uberl $^{\mathrm{a}}$ ndia & 650 & $2.70( \pm 0.20)$ & $4.05(3.64-4.46)$ & $49.1(40.9-58.8)$ & $16.46(13.72-20.80)$ & $30.4(22.1-41.6)$ & 9.11 & 0.17 \\
\hline Palmital & 650 & $3.84( \pm 0.30)$ & $5.86(5.49-6.28)$ & $71.0(60.2-83.6)$ & $15.69(13.35-19.47)$ & $28.9(21.3-39.1)$ & 5.09 & 0.41 \\
\hline
\end{tabular}

a $N=$ number of insects.

b Standard susceptible population.

Table 4. Relative toxicity of phosphine to ten populations of Oryzaephilus surinamensis

\begin{tabular}{|c|c|c|c|c|c|c|c|c|}
\hline Population & $N^{a}$ & $\begin{array}{c}\text { Slope } \\
( \pm \text { SEM })\end{array}$ & $\begin{array}{c}\mathrm{LC}_{50}(95 \% \mathrm{FL}) \\
\left(\mathrm{mg} \mathrm{L}^{-1}\right)\end{array}$ & $\begin{array}{c}\mathrm{RR}(95 \% \mathrm{CL}) \\
\mathrm{LC}_{50}\end{array}$ & $\begin{array}{c}\mathrm{LC}_{95}(95 \% \mathrm{FL}) \\
\left(\mathrm{mg} \mathrm{L}^{-1}\right)\end{array}$ & $\begin{array}{c}\mathrm{RR}(95 \% \mathrm{CL}) \\
\mathrm{LC}_{95}\end{array}$ & $\chi^{2}$ & $P$ \\
\hline Unaí-MG ${ }^{b}$ & 000 & $.01( \pm 0.10)$ & $0.03(0$ & - & $0.22(C$ & - & 5.17 & 0.16 \\
\hline Uberl $^{\mathrm{a}}$ ndia-MG & 450 & $6.11( \pm 0.70)$ & 0.06 & $1.9(1.6-2.1)$ & $0.11(C$ & $0.5(0.4-0.7)$ & 7.20 & 0.13 \\
\hline Unaí II-MG & 850 & $4.96( \pm 0.33)$ & $0.29(0.27-0.29)$ & $8.8(7.7-9.9)$ & $0.62(0.4$ & $2.8(2.3$ & 8.50 & 0.20 \\
\hline Sacramento-MG & 850 & $2.02( \pm 0.12)$ & $0.33(0.29-0.37)$ & $10.1(8.5-1$ & $2.15(1$ & $10.0(7.4-$ & 5.90 & 0.12 \\
\hline Viçosa-MG & 750 & $3.70( \pm 0.26)$ & $0.58(C$ & $17.7(15.4$ & $1.61(1$ & $7.5(5.9$ & 5.12 & 0.16 \\
\hline Bom Despacho-MG & 700 & $3.17( \pm 0.21)$ & $0.82(0$ & $25.1(21.7-2$ & $-3.37)$ & $12.6(9.5-16.6)$ & 5.17 & 0.16 \\
\hline Astolfo Dutra-MG & 600 & $2.41( \pm 0.21)$ & $0.93(0.82-1.04)$ & $28.6(24.3-33.7)$ & $4.51(3.61-6.11)$ & $20.9(15.1-29.0)$ & 5.65 & 0.23 \\
\hline Guaxupé-MG & 400 & $1.68( \pm 0.23)$ & $1.05(0.85-1.25)$ & $32.2(25.8-40.2)$ & $10.01(6.34-21.46)$ & $46.5(25.2-86.0)$ & 0.28 & 0.87 \\
\hline
\end{tabular}

a $N=$ number of insects.

${ }^{\mathrm{b}}$ Standard susceptible population.

the three species, as well as resistant populations (Tables 2, 3 and 4). There was a large variation in susceptibility within the populations of the three species. The concentration-mortality curves indicated that some populations of $T$. castaneum were highly resistant to phosphine ( $R R>100$-fold), while phosphine resistance levels ranged from low ( $R R<$ tenfold) to moderate $(10<\mathrm{RR}<100)$ for $R$. dominica and $O$. surinamensis (Tables 2,3 and 4 ).

\subsection{Respiration rate}

The production of carbon dioxide varied significantly among populations of $T$. castaneum $\left(F_{11,24}=37.2\right.$, $P<0.001), R$. dominica $\left(F_{9,21}=19.3, P<0.001\right)$ and $O$. surinamensis $\left(F_{7,17}=9.03, P<0.001\right)$ with 89,88 and $44 \%$ differences among them respectively. The populations with the highest carbon dioxide production had the smallest resistance ratio (RR) in all three species (Fig. 1). This finding provides support for the hypothesis that smaller respiration rates (carbon dioxide production) are correlated with higher resistance levels. A reduction in respiration results in a reduced uptake of the fumigant.

\subsection{Instantaneous rate of population increase $\left(r_{i}\right)$}

The instantaneous rate of population increase $r_{\mathrm{i}}$ was used to assess the fitness disadvantage associated

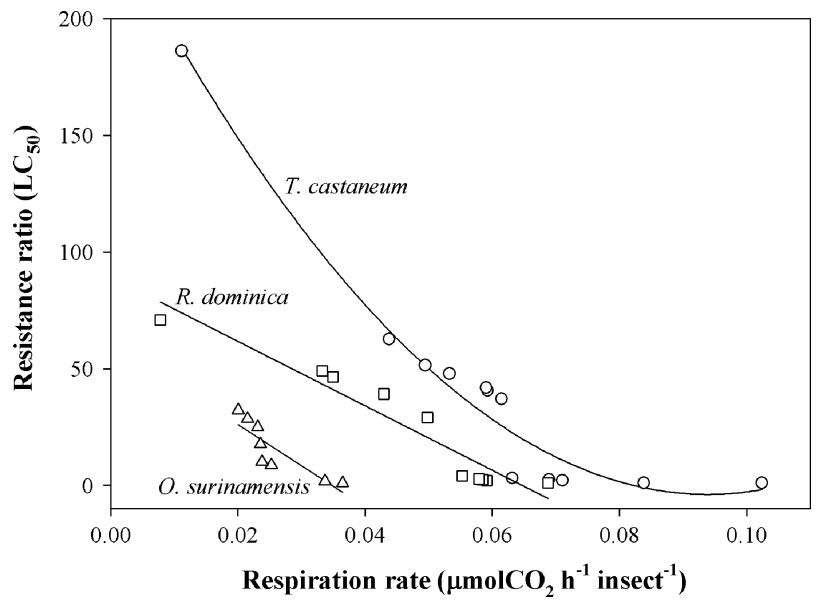

Figure 1. Resistance ratio at $\mathrm{LC}_{50}$ as a function of respiration rate (carbon dioxide production) of (O) Tribolium castaneum, ( $\square$ ) Rhyzopertha dominica and $(\triangle)$ Oryzaephilus surinamensis. Symbols represent the means of three replicates. Curves were fitted using regression analyses for $T$. castaneum

$\left(y=242.7-5249.9 x+27949.0 x^{2} ; r^{2}=0.97 ; F_{2,9}=125.0 ;\right.$

$P<0.001), R$. dominica $\left(y=89.4-1381.2 x ; r^{2}=0.91 ; F_{1,9}=51.7\right.$;

$P<0.001)$ and $O$. surinamensis $\left(y=61.4-1765.3 x ; r^{2}=0.75\right.$;

$\left.F_{1,7}=17.9 ; P=0.006\right)$.

with phosphine resistance in the absence of this fumigant. There was significant variation in $r_{\mathrm{i}}$ among populations of $T$. castaneum $\left(F_{11,108}=12.2, P<\right.$ $0.001), R$. dominica $\left(F_{9,90}=25.0, P<0.001\right)$ and 


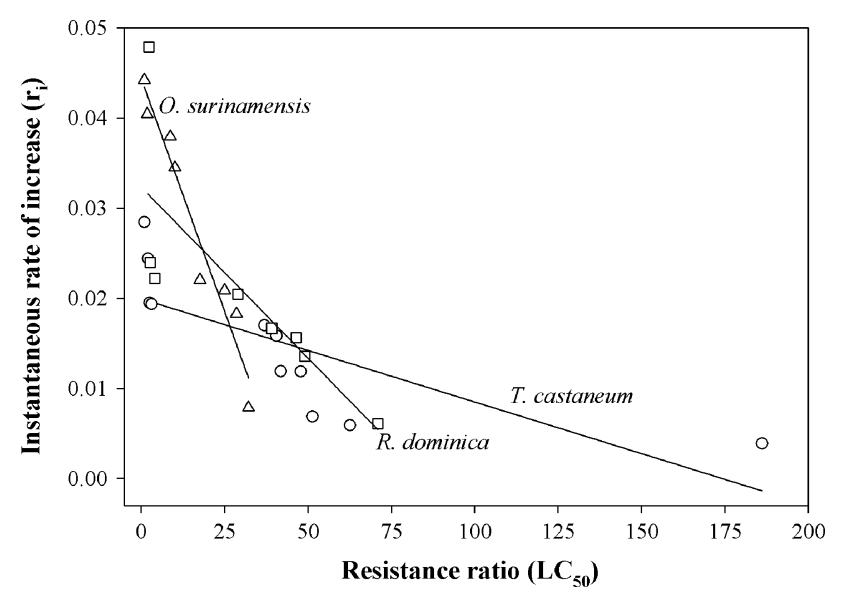

Figure 2. The instantaneous rate of population increase $r_{\mathrm{i}}$ for $(\mathrm{O})$ Tribolium castaneum, $(\square)$ Rhyzopertha dominica and $(\triangle)$ Oryzaephilus surinamensis as a function of resistance ratio $\left(\mathrm{LC}_{50}\right)$ for these species. Curves were fitted using linear regression analyses for $T$. castaneum $\left(y=0.02-0.0001 x ; r^{2}=0.60 ; F_{1,11}=13.5 ; P=0.005\right), R$. dominica $\left(y=0.032-0.0004 x ; r^{2}=0.62 ; F_{1,9}=9.9 ; P=0.02\right)$ and 0 . surinamensis $\left(y=0.044-0.001 x ; r^{2}=0.95 ; F_{1,7}=115.8 ; P<0.001\right)$.

O. surinamensis $\left(F_{7,72}=13.0, P<0.001\right)$ with 86,88 and $82 \%$ differences among populations respectively. For the three species, the populations with high $r_{\mathrm{i}}$ showed the smallest resistance ratio ( $R R$ for $L_{50}$ ) (Fig. 2). This indicates the existence of fitness costs associated with phosphine resistance.

\section{DISCUSSION}

The results of the present study show the occurrence of phosphine resistance in ten populations of $T$. castaneum, nine populations of $R$. dominica and seven populations of $O$. surinamensis from the states of Goiás, Mato Grosso, Minas Gerais and São Paulo (Tables 2, 3 and 4). This is the first report of phosphine resistance in stored-product pests in the states of Mato Grosso and Minas Gerais. Hence, phosphine resistance has spread in stored-product insect pests in Brazil compared with earlier surveys where phosphine resistance was a rare event and the resistance levels were low. ${ }^{7,10,12}$

The present study shows high resistance levels, with $86 \%$ of the populations containing resistant individuals. Some populations of $T$. castaneum (Bom Despacho-MG and Campos de Júlio-MT), $R$. dominica (Palmital-SP and Uberlândia-MG) and O. surinamensis (Guaxupé-MG) showed $\mathrm{LC}_{95}$ values higher than the recommended dose of phosphine (Tables 2, 3 and 4). These high $\mathrm{LC}_{95}$ values suggest that these populations have been under high selection pressure for many years. ${ }^{6}$ In addition, the movement of insects as a result of the trade of commodities is a likely contributor to the expansion of resistance to insecticides in stored-product insects. ${ }^{6,7}$

The physiological basis of phosphine resistance is not completely elucidated. However, the main mechanism of phosphine resistance is associated with the active exclusion of the gas. ${ }^{5,24,25}$ This mechanism results in a lower phosphine uptake by resistant insects compared with their susceptible counterparts. . $^{54,25}$ The present results of carbon dioxide production showed that respiration rate decreases with increase in phosphine resistance, indicating that the reduction in the respiration rate of the resistant populations in relation to the susceptible species is related to the reduced uptake of the fumigant by the resistant insects.

The hypothesis that the mechanism of phosphine resistance in stored-product pests is related to low uptake of the fumigant has been tested in studies using radioactive fumigants. These studies indicated that the mechanism of phosphine resistance is related to the reduction in the uptake of the compound, ${ }^{11}$ which had already been demonstrated in $R$. dominica, , $24,25^{5}$ T. castaneum, ${ }^{33}$ C. ferrugineus and O. surinamensis. ${ }^{34}$ The exposure of some populations of $R$. dominica, $S$. oryzae and $T$. castaneum to $\left[{ }^{32} \mathrm{P}\right]$-labelled phosphine showed that $\left[{ }^{32} \mathrm{P}\right]$ uptake by resistant strains of all three species tested was much lower than that by susceptible strains..$^{5,11,24}$ Under similar conditions of exposure $\left(0.7 \mathrm{~g} \mathrm{~m}^{-3}\right.$ of $\left[{ }^{32} \mathrm{P}\right] \mathrm{H}_{3}$ for $5 \mathrm{~h}$ at $\left.25^{\circ} \mathrm{C}\right)$, a susceptible strain of $T$. castaneum absorbed 7 times more gas per $g$ of insect than a resistant strain. The present data support such claims. 5,6,24,25,33,34 Moreover, the present results suggest that the lower phosphine uptake reported in phosphine-resistant populations of stored-product insect species might be caused by the reduction in the respiration rate of the resistant populations.

The results of the instantaneous rate of population increase $r_{i}$ of some insect populations showed that the resistant populations have smaller $r_{\mathrm{i}}$ than the susceptible populations. This result provides support for the hypothesis that the allocation of energy for the production of defence mechanisms against insecticides in the resistant populations would reduce their reproductive performance. ${ }^{23}$ This adaptative cost of insecticide resistance is a frequent assumption in models of insecticide resistance evolution, ${ }^{18,35}$ and was therefore expected.

The assumption of a fitness cost associated with insecticide resistance is based on the acquisition of adaptation to a new environment, an insecticidecontaminated one. ${ }^{18}$ This was the case for the phosphine-resistant populations from the three storedproduct insect species studied here. The present data confirm earlier findings showing that resistant populations of $S$. oryzae, S. zeamais and C. ferrugineus had lower fecundity and intrinsic growth rates $\left(r_{\mathrm{m}}\right)$ compared with susceptible populations. ${ }^{16,17,19}$

Regarding a more applied perspective, note that some resistant genotypes demonstrated fitness costs associated with insecticide resistance. In these cases, resistance management strategies that are based on the suppression of phosphine use, aiming to reestablish its susceptibility and the eventual reintroduction of the fumigant, can be used. This management tactic is important because of the lack of alternative fumigants for use in stored-product protection. 


\section{ACKNOWLEDGEMENTS}

The authors would like to thank AP Neto and FM Garcia for technical assistance, AF Rozado, V Arthur, CL Cardoso and DP Cardoso for providing T. castaneum, $R$. dominica and O. surinamensis populations used in this study and the Companhia de Armazéns e Silos do Estado de Minas Gerais (CASEMG), Cooperativa Agroindustrial dos Produtores Rurais do Sudoeste Goiano (COMIGO) and Companhia de Entrepostos e Armazéns Gerais de São Paulo (CEAGESP) for allowing insect sampling in their storage facilities. They thank Arne Janssen (Visiting Fellow supported by the CAPES Foundation, Brazilian Ministry of Education) for the language review. Financial support by the CAPES Foundation (MAGP), the National Council of Scientific and Technological Development $-\mathrm{CNPq}$ and the Minas Gerais State Agency for Research Aid - FAPEMIG (LRD'AF and RNCG) is also greatly appreciated.

\section{REFERENCES}

1 Price LA and Mills KA, The toxicity of phosphine to the immature stages of resistant and susceptible strains of some common stored product beetles, and implications for their control. I Stored Prod Res 24:51-59 (1988).

2 Chaudhry MQ, Phosphine resistance. Pestic Outlook 11:88-91 (2000).

3 Subramanyam B and Hagstrum DW, Resistance measurement and management, in Integrated Management of Insects in Stored Products, ed. by Subramanyam Bh and Hagstrum DW. Marcel Dekker, New York, NY, USA, pp. 331-397 (1996).

4 Cheng Q, Valmas N, Reilly PEB, Collins PJ, Kopittke R and Ebert PR, Caenorhabditis elegans mutants resistant to phosphine toxicity show increased longevity and cross-resistance to the synergistic action of oxygen. Toxicol Lett 73:60-65 (2003).

5 Chaudhry MQ and Price NR, Insect mortality at doses of phosphine which produce equal uptake in susceptible and resistant strains of Rhyzopertha dominica (F.) (Coleoptera: Bostrichidae). 7 Stored Prod Res 26:101-107 (1990).

6 Benhalima H, Chaudhry MQ, Mills KA and Price NR, Phosphine resistance in stored-product insects collected from various grain storage facilities in Morocco. F Stored Prod Res 40:241-249 (2004).

7 Champ BR and Dyte CE, Informe de la Prospeccion Mundial de la FAO sobre Susceptibilidad a los Insecticidas de las Plagas de Granos Almacenados. FAO, Rome, Italy (1976).

8 Montreal Protocol on Substances that Deplete the Ozone Layer. 1994 Report of the Methyl Bromide Technical Options Committee. 1995 Assessment, UNEP, Nairobi, Kenya (1995).

9 Tyler RS, Taylor RW and Rees DP, Insect resistance to phosphine fumigation in food warehouses in Bangladesh. Internat Pest Cont 35:10-21 (1983).

10 Pacheco IA, Sartori MR and Taylor RWD, Levantamento de resistência de insetos-praga de grãos armazenados à fosfina, no estado de São Paulo. Col ITAL 20:144-154 (1990).

11 Chaudhry MQ, A review of the mechanisms involved in the action of phosphine as an insecticide and phosphine resistance in stored-product insects. Pestic Sci 49:213-228 (1997).

12 Sartori MR, Pacheco IA and Vilar RM, Resistance to phosphine in stored grain insects in Brazil, Proc Fifth Internat Working Conference on Stored-Product Protection, ed. by FleuratLessard F. INRA, Bordeaux, France, pp. 1041-1050 (1990).

13 Roush RT and Tabashnik BE, Pesticide Resistance in Arthropods. Chapman and Hall, New York, NY, USA (1990).
14 Haubruge E and Arnaud A, Fitness consequences of malathionspecific resistance in red flour beetle (Coleoptera: Tenebrionidae) and selection for resistance in the absence of malathion. f Econ Entomol 94:552-557 (2001).

15 McKenzie JA, Ecological and Evolutionary Aspects of Insecticide Resistance. Academic, Austin, TX, USA (1996).

16 White NDG and Bell RJ, Relative fitness of a malathionresistant strain of Cryptolestes ferrugineus (Coleoptera: Cucujidae) when development and oviposition occur in malathiontreated and untreated wheat kernels. I Stored Prod Res 26:23-37 (1990).

17 Longstaff BC, An experimental study of the fitness of susceptible and resistant strains of Sitophilus oryzae (L.) (Coleoptera: Curculionidae) exposed to insecticide. I Stored Prod Res 27:75-82 (1991).

18 Coustau C, Chevillon C and ffrench-Constant RH, Resistance to xenobiotics and parasites: can we count the cost? Trends Ecol Evol 15:378-383 (2000).

19 Fragoso DB, Guedes RNC and Peternelli LA, Developmental rates and population growth of insecticide-resistant and susceptible populations of Sitophilus zeamais. F Stored Prod Res 41:271-281 (2005).

20 Arnaud L and Haubruge E, Insecticide resistance enhances male reproductive success in a beetle. Evolution 56:2435-2444 (2002).

21 Baker JE, Perez-Mendoza J, Beeman RW and Throne JE, Fitness of a malathion-resistant strain of the parasitoid Anisopteromalus calandrae (Hymenoptera: Pteromalidae). $\mathcal{J}$ Econ Entomol 91:50-55 (1998).

22 Oppert B, Hammel R, Throne JE and Kramer K, Fitness cost of resistance to Bacillus thuringiensis in the Indianmeal moth, Plodia interpunctella. Entomol Exp Appl 96:281-287 (2000).

23 Guedes RNC, Oliveira EE, Guedes NMP, Ribeiro B and Serrão JE, Cost and mitigation of insecticide resistance in the maize weevil, Sitophilus zeamais. Physiol Entomol 31:30-38 (2006).

24 Price NR, A comparison of the uptake and metabolism of ${ }^{32} \mathrm{P}$ radiolabelled phosphine in susceptible and resistant strains of the Lesser Grain Borer (Rhyzopertha dominica). Comp Biochem Physiol 69C:129-131 (1981).

25 Price NR, Active exclusion of phosphine as a mechanism of resistance in Rhyzopertha dominica (F.) (Coleoptera: Bostrichidae). I Stored Prod Res 20:163-168 (1984).

26 Emekci M, Navarro S, Donahaye E, Rindner M and Azrieli A, Respiration of Tribolium castaneum (Herbst) at reduced oxygen concentrations. F Stored Prod Res 38:413-425 (2002).

27 Emekci M, Navarro S, Donahaye E, Rindner M and Azrieli A, Respiration of Rhyzopertha dominica (F.) at reduced oxygen concentrations. F Stored Prod Res 40:27-38 (2004).

28 Recommended methods for the detection and measurement of resistance of agricultural pests to pesticides. 16: Tentative method for adults of some stored cereals, with methyl bromide and phosphine. FAO Plant Prot Bull 23:12-25 (1975).

29 Oliveira EE, Guedes RNC, Corrêa AS, Damasceno BL and Santos CT, Resistência vs Susceptibilidade a Piretróides em Sitophilus zeamais Motschulsky (Coleoptera: Curculionidae): Há Vencedor? Neotrop Entomol 34:981-990 (2005).

30 Walthall WK and Stark JD, A comparison of acute mortality and population growth rate as endpoints of toxicological effect. Ecotoxicol Environ Safe 37:45-52 (1997).

31 SAS/STAT User's Guide, v. 6. SAS Institute, Cary, NC, USA (1997).

32 Robertson JL and Preisler HK, Pesticide Bioassays with Arthropods. CRC Press, Boca Raton, FL, USA (1992).

33 Nakakita $\mathrm{H}$ and Kuroda J, Differences in phosphine uptake between susceptible and resistant strains of insects. $\mathcal{F}$ Pestic Sci 11:21-26 (1986).

34 Price NR and Dance SJ, Some biochemical aspects of phosphine action and resistance in three species of stored product beetles. Comp Biochem Physiol 76C:277-281 (1983).

35 Roush RT and McKenzie JA, Ecological genetics of insecticide and acaricide resistance. Annu Rev Entomol 32:361-380 (1987). 